\title{
Using oyster tissue toxicity as an indicator of disturbed environments
}

\author{
T. A. Palmer $\cdot$ P. Uehling $\cdot$ J. B. Pollack
}

Received: 21 August 2014/Revised: 2 December 2014/Accepted: 30 December 2014/Published online: 17 February 2015

(C) Islamic Azad University (IAU) 2015

\begin{abstract}
Crassostrea virginica (the Eastern or American oyster) bioaccumulates pollutants from the water column, and therefore, its tissues can be used as bioindicators of past and present estuarine health. In this pilot project, we decided to investigate whether its tissues would be a suitable medium for toxicity testing using tissues from a variety of southern Texas locations of known and suspected anthropogenically impacted and unimpacted areas. We also conducted toxicity tests on sediments adjacent to oyster reefs using standard protocols for sediment toxicity. We tested the toxicity of tissues and sediments on the luminescent bacteria Vibrio fischeri, whose bioassays are commonly referred to by the trade name Microtox ${ }^{\circledR}$. Microtox tests are quick, relatively inexpensive and sensitive to a range of contaminants. Evidence from this preliminary study suggests that conducting toxicity tests on oyster tissues may predict localized contamination better than when conducting toxicity tests on subtidal sediment. The refinement of these methods to use oyster tissues to detect contamination may be especially useful for environmental impact studies and/or studies where rapid and inexpensive information is needed.
\end{abstract}

Keywords Oyster - Toxicity · Pollution - Crassostrea virginica $\cdot$ Microtox

\section{Introduction}

Bivalve molluscs are considered sentinels for aquatic health because they are sedentary, filter their food from the water column, incorporate contaminants in their tissues and are relatively long-lived so assimilate contaminants over long time periods (Farrington 1983; Boening 1999). In the USA, the Eastern (or American) oyster, Crassostrea virginica, has been used for estuarine health monitoring because of their ability to bioaccumulate pollutants, including trace metals, pesticides, PCBs, DDT and other organic contaminants (Presley et al. 1990; Sericano et al. 1990a, b; Jackson et al. 1994; Sericano et al. 1996; Aguilar et al. 2012). However, the laboratory analysis of a large suite of contaminants present in oyster tissues can be expensive and time consuming.

The quality of aquatic environments may be assessed using a variety of methods (Day et al. 1995; Weideborg et al. 1997). Toxicity bioassays are a common technique that can be used to test for the presence and biological effects of a single or combination of contaminants (e.g., Sprague 1969; Couillard et al. 2009). The bacteria Vibrio fischeri (Beijerinck 1889; formerly Photobacterium phosphoreum) has been used successfully in toxicity bioassays to determine environmental quality (e.g., Kwan and Dutka 1992; Carr et al. 1996; Jennings et al. 2001; Morehead et al. 2008, Girotti et al. 2008). The most common V. fischeri bioassays, frequently used in methodologies under the trade name Microtox ${ }^{\circledR}$ (Johnson 2005), have the advantage of being fast, simple, inexpensive and sensitive to a range of contaminants (Ribo and Kaiser 1987; Ramaiah and Chandramohan 1993). The history of environmental contamination in aquatic systems can be found in the underlying sediments because of adsorption to sediment grains and gravity. However, problems with using the
T. A. Palmer $(\bowtie) \cdot$ P. Uehling · J. B. Pollack

Texas A\&M University-Corpus Christi, 6300 Ocean Drive, Unit 5869, Corpus Christi, TX 78412-5869, USA

e-mail: terry.palmer@tamucc.edu 
Microtox sediment bioassays have been identified when there are differences in sediment grain size and/or subsequent turbidity, $\mathrm{pH}$ and color of the sample solution used in the toxicity test (Ribo and Kasier 1987; Campisi et al. 2005; Lappalainen et al. 2001).

Oysters have significant exposure to contaminants through their suspension-feeding activities and relatively immobile living positions (Salazar and Salazar 1997). The aim of this pilot study is to determine whether there is evidence to suggest that oyster $(C$. virginica) tissues can be used as an alternative to sediment in Microtox bioassays as indicators of estuarine health. The secondary aim is to determine whether the relative toxicity of oyster tissues mirrors that of the surrounding sediments. Results have important implications for the detection of environmental contamination of aquatic systems, such as those due to the Deepwater Horizon oil spill that occurred in the Gulf of Mexico in 2010. This study occurred in Texas, USA, in June and July 2013.

\section{Materials and methods}

Nine subtidal sites in three South Texas, USA, estuaries in the northwestern Gulf of Mexico were sampled for oysters and sediment between 20 June and 18 July 2013 (Table 1; Fig. 1). Each site was a priori categorized as being in either a 'disturbed' or a 'natural' environment. Site selection was based on local knowledge and documentation of historic and recent water and sediment chemistries (predominantly found in Montagna and Palmer 2012). A site was labeled 'disturbed' if it was in close proximity to urban structures such as breakwaters and buildings or was in a location known to have sediment contamination issues. There is known industrial runoff and documented zinc and copper legacy contamination in Nueces Bay (Nicolau and Hill 2011; Montagna and Palmer 2012). The Corpus Christi Bay site is in close proximity to the Corpus Christi inner harbor and the Corpus Christi marina. The concentrations of arsenic, copper and lead in Corpus Christi inner harbor has frequently exceeded the Texas Commission for Environmental Quality (TCEQ) standards for water quality (Montagna and Palmer 2012). The Laguna Madre A site is adjacent to a small marina, where boat cleaning and the fueling of boats occur.

A site was labeled as 'natural' if it was far $(>1 \mathrm{~km})$ from any significant urban development. It is likely that these 'natural' sites are affected by humans in some way (e.g., indirect agricultural runoff); however, the impacts are low relative to the disturbed sites. No large-scale persistent major concentrations of non-nutrient contaminants have been reported in the water or sediments in Aransas Bay, St. Charles Bay or the upper Laguna Madre (Montagna and Palmer 2012).

Six to eight live oysters $(C$. virginica) and three sediment samples were collected from each site during the summer of 2013. Sediment was sampled to a depth of $3 \mathrm{~cm}$ using a handheld 6.3-cm-diameter core and homogenized. Samples were refrigerated at approximately $4{ }^{\circ} \mathrm{C}$ and assessed for toxicity within $72 \mathrm{~h}$. At each site, water column salinity was measured, and additional cores were collected for sediment grain size analysis. The proportion of four sediment size classes (rubble, sand, silt and clay) in each sample was determined using a combination of sieving (for sand and rubble) and the pipette method (for silt and clay) following the methods of Folk (1965).

Sediment and oyster toxicity were assessed using the Microtox ${ }^{\circledR}$ basic solid-phase test (BSPT, Strategic Diagnostics Inc. 2009). The BSPT exposes the luminescent bacteria $V$. fischeri, which loses luminescence as the toxicity of a sample increases. For each sample, aliquots of $V$. fischeri were simultaneously exposed to different concentrations of oyster tissue or sediment to measure the loss in luminescence and calculate an effective concentration 50 (EC50). The EC50 is the concentration (of tissue or sediment) that causes a $50 \%$ loss in luminescence (Ribo and

Table 1 Site descriptions

\begin{tabular}{lllll}
\hline Site & Site name & Latitude & Longitude & Disturbed/natural \\
\hline CC & Corpus Christi Bay & 28.815040 & -97.389803 & Disturbed \\
AB & Aransas Bay & 28.122456 & -96.971354 & Natural \\
NB-A & Nueces Bay A & 27.825708 & -97.418545 & Disturbed \\
NB-B & Nueces Bay B & 27.828702 & -97.417512 & Disturbed \\
NB-C & Nueces Bay C & 27.858187 & -97.376730 & Disturbed \\
LM-A & Laguna Madre A & 27.631827 & -97.240632 & Disturbed \\
LM-B & Laguna Madre B & 27.620553 & -97.212667 & Natural \\
CB & Copano Bay & 28.135497 & -97.053484 & Natural \\
SC & St. Charles Bay & 28.123960 & -96.971800 & Natural \\
\hline
\end{tabular}

a (psu) at time of sampling 


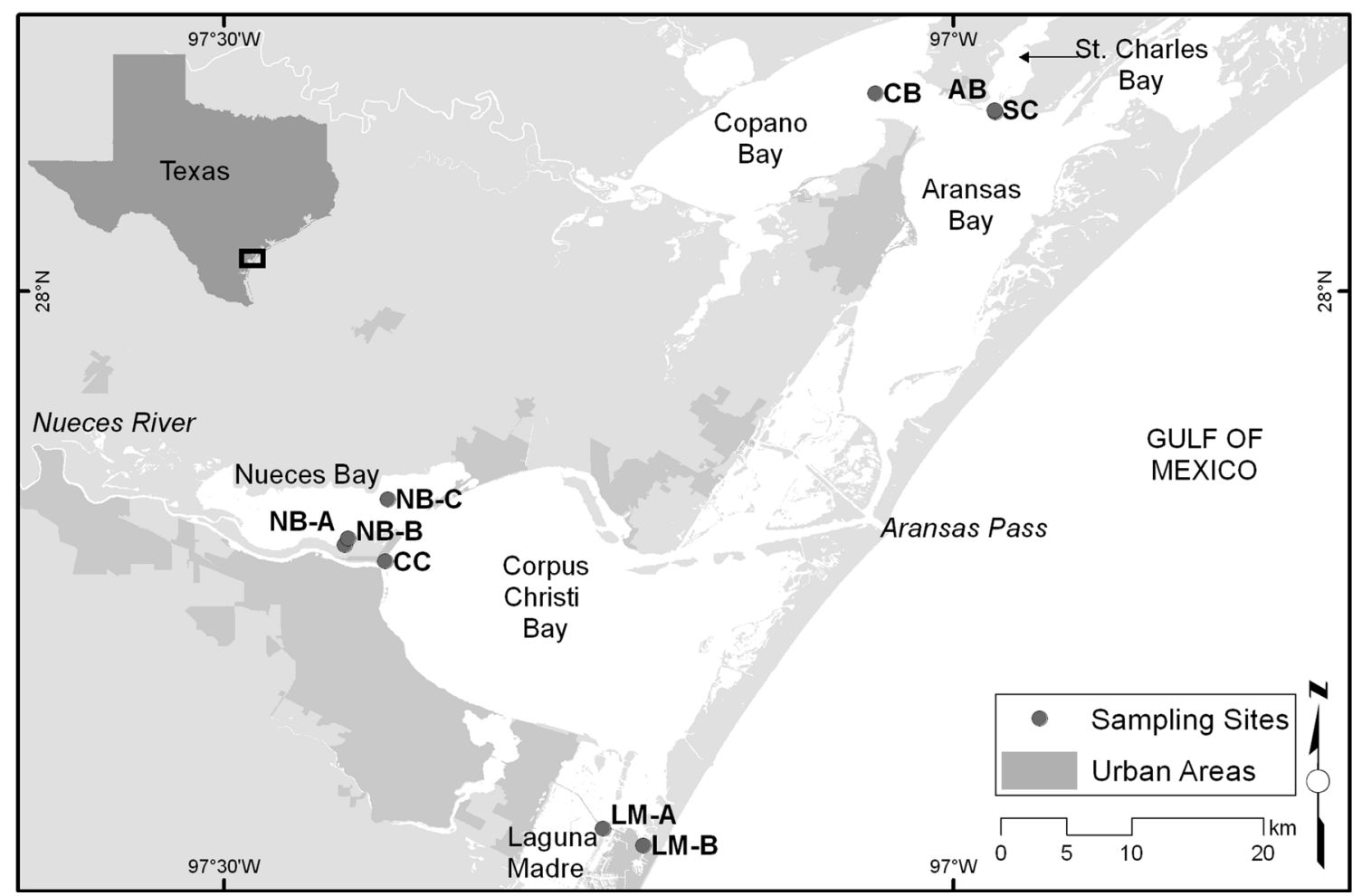

Fig. 1 Nine subtidal sites in three South Texas estuaries in the western Gulf of Mexico were sampled for oysters and sediment. Sites were classified as 'disturbed' or 'natural'; see Table 1

Kaiser 1987). The EC50 was then converted to toxicity units $\left(\mathrm{TU}=100 / \mathrm{EC} 50\right.$ in $\left.\mathrm{mg} \mathrm{l}^{-1}\right)$ to increase interpretability of the result (TU values are proportional to toxicity, whereas EC50 values are inversely proportional to toxicity).

Sediment tests were completed according to the standard BSPT protocol, using a maximum sediment concentration of $7 \mathrm{~g}$ sediment per $35 \mathrm{ml}$ diluent $(2 \% \mathrm{NaCl})$. Oyster tests used homogenized tissue from one to three oysters $(4-18 \mathrm{~g})$ in $50 \mathrm{ml}$ of diluent and used as the maximum concentration. Three replicate toxicity tests were run for each site for both sediment and oyster samples. A Microtox ${ }^{\circledR}$ Model 500 Analyzer was used with standard protocols of 30-min exposure time to the sample (Strategic Diagnostics Inc. 2009; now distributed by Modern Water Inc., Delaware).

To determine the dry-to-wet ratio of each sample, $5 \mathrm{ml}$ of each sample in suspension were weighed and dried for at least $24 \mathrm{~h}$. The conversion to dry weight was recommended by Ross et al. (1999) to account for any differences in water content among oyster and sediment samples. TU values were then recalculated using maximum concentrations of sediment/tissue as a dry weight.

A one-way ANOVA was used to determine the difference in TU values for oyster and sediment samples from the nine sites. Tukey's pairwise comparisons were used to determine differences between individual sites following the ANOVA tests. Data were log transformed to improve normality prior to the ANOVA. Spearman's rank correlations were used to determine linear correlations between sediment and oyster TU values. To ensure that oyster size did not have an effect on tissue toxicity, the size (length) of the oysters analyzed was correlated with tissue toxicity (TU). Sediment and oyster TU values were also correlated with salinity and sediment grain size groupings (rubble, sand, silt and clay) to determine whether basic environmental variables were related to oyster and sediment toxicity.

\section{Results and discussion}

The toxicities of the oyster tissues (TU) were significantly different from each other among sites ( $p \leq 0.0015$; Fig. 2a), with toxicities from the disturbed sites tending to be higher than those from natural sites. Oyster tissue toxicity from Nueces B, a disturbed site, was significantly higher than from the Aransas Bay, Laguna Madre B and St Charles Bay sites, all of which were labeled natural sites. The toxicities of oyster tissues from other sites were not significantly different from each other.

Sediment toxicity was also significantly different among sites $(p<0.0001$; Fig. 2b). However, the four lowest 

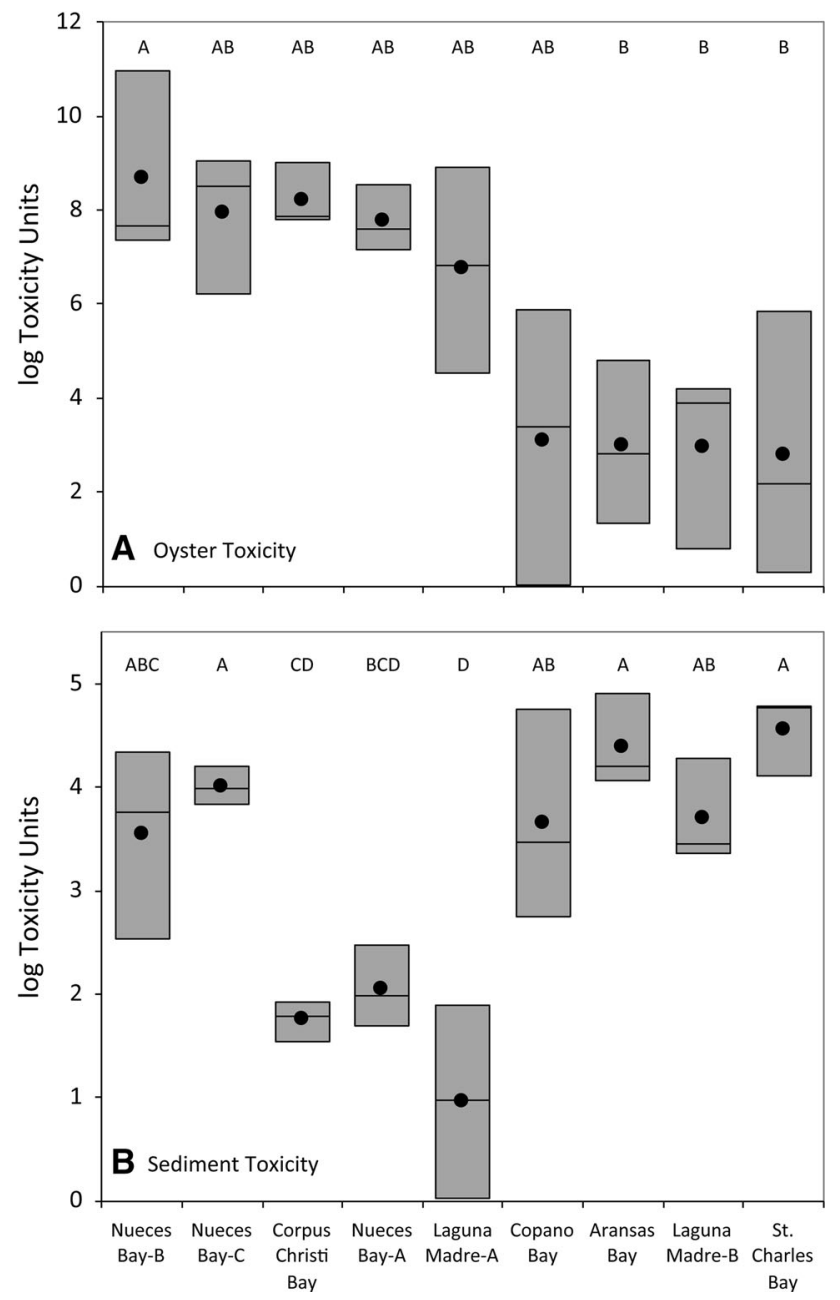

Fig. 2 Toxicity of a dry oyster tissue and $\mathbf{b}$ dry sediment collected from nine sites. Boxes represent the minimum, median and maximum values. Dots represent the mean. Letters indicate Tukey's groupings

toxicities were observed in four of the five sites that were labeled as disturbed (Laguna Madre A, Corpus Christi Bay, Nueces A and Nueces B). The two highest mean sediment toxicities were observed in two natural sites (St. Charles and Aransas Bays).

The dry- and wet-weight toxicities of the corresponding sediment and oyster tissues were highly correlated with each other. The Spearman's correlation between wet and dry sediment toxicities was 0.96 , and between wet and dry oyster toxicities was 0.99 (both $p<0.0001)$. Dry oyster toxicities were weakly negatively correlated with dry sediment toxicities $(r=-0.42 ; p \leq 0.0313)$.

Oyster toxicity was not correlated with salinity or any of the four grain size groups. However, sediment toxicity was correlated with silt $(r=0.80 ; p \leq 0.0096)$ and clay concentrations $(r=0.70 ; p \leq 0.0358)$. The toxicity of oyster tissues was not correlated with oyster size $(r=-0.17$; $p \leq 0.3991)$.
The amount of toxic content in an organism depends on contaminant concentration in the environment, its bioavailability and bioaccumulation (Cotou et al. 2002). The toxicity of oyster tissues as determined by the Microtox BSPT was as expected, with the lowest toxicities occurring at the natural sites and highest toxicities occurring at the most disturbed sites. This supports previous research by Lau-Wong (1990), where tissues extracted from mussels and clams demonstrated changes in luminescence in Microtox bioassays that were related with their degree of toxic content.

The relative toxicities of the surrounding sediments in the current study did not mirror those of the oyster tissues, and the differences between natural and disturbed sites were inconsistent. The unexpected differences in toxicity among sediment samples is most likely due to differences in sediment grain size because toxicity was significantly correlated with the concentration of silt and clay in the sediment. Sediment grain size is known to confound toxicity results in Microtox sediment bioassays (Ringwood et al. 1997) and was an impetus in this study for assessing the use of oyster tissue as an alternate indicator of toxicity. Sediments with high clay concentrations can demonstrate increased toxicity values (low EC50 values) due to interference caused by the adsorption of the bacteria $V$. fischeri onto these fine sediment particles (Ringwood et al. 1997). This documented grain size bias is consistent with results in this current study where samples with expected low toxicity, but high silt and clay contents have apparent higher toxicity than expected.

Color and turbidity of sediments, which can be related to grain size distributions, have also been shown to affect apparent toxicities as assessed by Microtox BSPT (Campisi et al. 2005; Lappalainen et al. 2001). Toxicity tests using a solvent extraction of contaminants can resolve problems with grain size in toxicity tests; however, solvents can prove toxic to the bacteria and will not necessarily represent the bioavailable contaminants (Tay et al. 1992; Mariscal et al. 2003; Doe et al. 2005). Steps using controls for factors such as sediment grain size and color correction can be made; however, this requires a comprehensive set of testing using uncontaminated sediment of similar physical properties. Finding uncontaminated sediment with similar properties can be difficult. The uniform consistency of oyster tissues among sites (relative to the sediments) makes them more appropriate for Microtox bioassays without the need for solvents to extract contaminants.

\section{Conclusion}

This pilot study shows promise that oyster tissues have the potential to be a better medium to use in Microtox toxicity 
tests than unmodified sediment when determining the contamination exposure among estuarine locations. Among biological effect methods, strong correlations have been shown between Microtox and the more complex scope-forgrowth method, suggesting the easier to use Microtox is a reasonable alternative for assessing the quality of marine coastal environments (Cotou et al. 2002). However, an obvious limitation of this method is that it is restricted to the areas of estuaries that have, and continue to have, oyster populations. Nevertheless, if a suitable target area contains oyster populations, this simple and inexpensive assessment of estuarine disturbance might be useful. Further detailed studies using oysters and sediments with known quantities of contamination by specific toxicants will be useful in determining the full extent in which oyster tissues can be used as a medium for contaminant exposure.

Acknowledgments The initial idea for this trial study came after seeing the work by Beth Falls and others from Ocean Research and Conservation Association (ORCA) in Ft. Pierce, FL. Oysters have been used as sentinel species for time series and disturbance monitoring research by this group. Paige Uehling was funded by the National Science Foundation's (NSF) Research Experience for Undergraduates (REU) program (Grant No. DBI-1004903: SURFSummer Undergraduate Research Focus) during the fieldwork and laboratory components of this study. Uehling was also a student at Bucknell University during this period. We thank Dr. Kim Withers for assisting Uehling with REU program logistics and support.

\section{References}

Aguilar CA, Montalvo C, Rodríguez L, Cerón JG, Cerón RM (2012) American oyster (Crassostrea virginica) and sediments as a coastal zone pollution monitor by heavy metals. Int J Environ Sci Technol 9:579-586. doi:10.1007/s13762-012-0078-y

Beijerinck MW (1889) Le Photobacterium luminosum, bactérie lumineuse de la Mer du Nord. Arch Neerl Sci Exact Nat 23:401-405

Boening DW (1999) An evaluation of bivalves as biomonitors of heavy metals pollution in marine waters. Environ Monit Assess 55:459-470. doi:10.1023/A:1005995217901

Campisi T, Abbondanzi F, Casado-Martinez C, Delvalls TA, Guerra R, Iacondini A (2005) Effect of sediment turbidity and color on light output measurement for Microtox basic solid-phase test. Chemosphere 60:9-15. doi:10.1016/j.chemosphere.2004.12.052

Carr RS, Long ER, Chapman DC, Thursby G, Biedenbach JM, Windom H, Sloane G, Wolfe DA (1996) Toxicity assessment studies of contaminated sediments in Tampa Bay, Florida. Environ Toxicol Chem 15:1218-1231. doi:10.1002/etc. 5620150730

Cotou E, Papathanassiou E, Tsangaris C (2002) Assessing the quality of marine coastal environments: comparison of scope for growth and Microtox bioassay results of pollution gradient areas in eastern Mediterranean (Greece). Environ Pollut 119:141-149. doi:10.1016/S0269-7491(01)00337-2

Couillard CM, Laplatte B, Pelletier E (2009) A fish bioassay to evaluate the toxicity associated with the ingestion of benzo [a] pyrene-contaminated benthic prey. Environ Toxicol Chem 28:772-781. doi:10.1897/08-092R.1
Day KE, Dutka BJ, Kwan KK, Batista N, Reynoldson TB, MetcalfeSmith JL (1995) Correlations between solid-phase microbial screening assays, whole-sediment toxicity tests with macroinvertebrates and in situ benthic community structure. J Great Lakes Res 21:192-206. doi:10.1016/S0380-1330(95)71031-0

Doe K, Jackman P, Scroggins R, Mcleay D, Wohlgeschaffen G (2005) Solid-phase test for sediment toxicity using the luminescent bacterium, Vibrio fischeri. In: Blaise C, Férard J-F (eds) Small-scale freshwater toxicity investigations. Springer, Dordrecht, pp 107-136

Farrington JW (1983) Bivalves as sentinels of coastal chemical pollution - the mussel (and oyster) watch. Oceanus 26:18-29

Folk RL (1965) Petrology of sedimentary rocks. Hemphill, Austin

Girotti S, Ferri EN, Fumo MG, Maiolini E (2008) Monitoring of environmental pollutants by bioluminescent bacteria. Anal Chim Acta 608:2-29. doi:10.1016/j.aca.2007.12.008

Jackson TJ, Wade TL, McDonald TJ, Wilkinson DL, Brooks JM (1994) Polynuclear aromatic hydrocarbon contaminants in oysters from the Gulf of Mexico (1986-1990). Environ Pollut 83:291-298. doi:10.1016/0269-7491(94)90150-3

Jennings VLK, Rayner-Brandes MH, Bird DJ (2001) Assessing chemical toxicity with the bioluminescent photobacterium (Vibrio fischeri): a comparison of three commercial systems. Water Res 14:3448-3456. doi:10.1016/S0043-1354(01)00067-7

Johnson BT (2005) Microtox ${ }^{\circledR}$ acute toxicity test. In: Blaise C, Férard J-F (eds) Small-scale freshwater toxicity investigations. Springer, Dordrecht, pp 69-105

Kwan KK, Dutka BJ (1992) Evaluation of toxi-chromotest direct sediment toxicity testing procedure and Microtox solid-phase testing procedure. B Environ Contam Toxicol 49:656-662. doi:10.1007/BF00200777

Lappalainen J, Juvonen R, Nurmi J, Karp M (2001) Automated color correction method for Vibrio fischeri toxicity test. Comparison of standard and kinetic assays. Chemosphere 45:635-641. doi:10. 1016/S0045-6535(00)00579-8

Lau-Wong MM (1990) Assessing the effectiveness of depuration of polluted clams and mussels using the Microtox ${ }^{\circledR}$ bioassay. Bull Environ Contam Toxicol 44:876-883. doi:10.1007/BF01702178

Mariscal A, Peinado MT, Carnero-Varo M, Fernández-Crehuet J (2003) Influence of organic solvents on the sensitivity of a bioluminescence toxicity test with Vibrio harveyi. Chemosphere 50:349-354. doi:10.1016/S0045-6535(02)00312-0

Montagna PA, Palmer TA (2012) Water and sediment quality status and trends in the coastal bend area-phase 2: data analysis. Report submitted to the Coastal Bend Bays and Estuaries program for project 1206. Texas A\&M University-Corpus Christi, Harte Research Institute for Gulf of Mexico Studies, pp 520

Morehead S, Montagna P, Kennicutt MC II (2008) Comparing fixedpoint and probabilistic sampling designs for monitoring the marine ecosystem near McMurdo Station, Ross Sea, Antarctica. Antarct Sci 20:471-484. doi:10.1017/S0954102008001326

Nicolau BA, Hill EM (2011) Nueces Bay total maximum daily load project-year-five implementation effectiveness monitoring data report. Texas Commission on Environmental Quality, Texas, p 62

Presley RJ, Taylor RJ, Boothe PN (1990) Trace metals in Gulf of Mexico oysters. Sci Total Environ 97(98):551-553. doi:10.1016/ 0048-9697(90)90263-T

Ramaiah N, Chandrmohan D (1993) Ecological and laboratory studies on the role of luminous bacteria and their luminescence in coastal pollution surveillance. Mar Pollut Bull 26:190-201. doi:10.1016/0025-326X(93)90621-P

Ribo JM, Kaiser KLE (1987) Photobacterium Phosphoreum toxicity bioassay. I. Test procedures and applications. Toxic Assess 2:305-323. doi:10.1002/tox.2540020307 
Ringwood AH, Delorenzo ME, Ross PE, Holland AF (1997) Interpretation of Microtox solid-phase toxicity tests: the effects of sediment composition. Environ Toxicol Chem 16:1135-1140. doi:10.1002/etc.5620160607

Ross P, Burton GA, Greene M, Ho K, Meier P, Sweet L, Auwarter A, Bispo A, Doe K, Erstfeld K, Goudey S, Goyvaerts M, Henderson D, Jourdain M, Lenon M, Pandard P, Qureshi A, Rowland C, Schipper C, Schreurs W, Trottier S, Van Aggelen G (1999) Interlaboratory precision study of a whole sediment toxicity test with the bioluminescent bacterium Vibrio fischeri. Environ Toxicol 14:339-345. doi:10.1002/(SICI)1522-7278(199907)14: 3<339:AID-TOX7>3.0.CO;2-R

Salazar MH, Salazar SM (1997) Using bioaccumulation and growth in caged intertidal oysters to assess oil exposure and effects in Delaware Bay. In: Proceedings of 20th Arctic Marine Oilspill Program (AMOP) vol 1. pp 661-675

Sericano JL, Atlas EL, Wade TL, Brooks JM (1990a) NOAA's status and trends mussel watch program: chlorinated pesticides and PCB's in oysters (Crassostrea virginica) and sediments from the Gulf of Mexico, 1986-1987. Mar Environ Res 29:161-203. doi:10.1016/0141-1136(90)90033-K
Sericano JL, Wade TL, Atlas EL, Brooks JM (1990b) Historical perspective on the environmental bioavailability of DDT and its derivatives to Gulf of Mexico oysters. Environ Sci Technol 24:1541-1548. doi:10.1021/es00080a014

Sericano JL, Wade TL, Brooks JM (1996) Accumulation and depuration of organic contaminants by the American oyster (Crassostrea virginica). Sci Total Environ 179:149-160. doi:10. 1016/0048-9697(96)90054-6

Sprague JB (1969) Measurement of pollutant toxicity to fish I. Bioassay methods for acute toxicity. Water Res 3:793-821. doi:10.1016/0043-1354(69)90050-5

Strategic Diagnostics Inc (2009) Microtox ${ }^{\circledR}$ basic solid-phase test (Basic SPT). Strategic Diagnostics Inc, Newark

Tay K-L, Doe KG, Wade SJ, Vaughan JDA, Berrigan RE, Moore MJ (1992) Sediment bioassessment in Halifax Harbour. Environ Toxicol Chem 11:1567-1581. doi:10.1002/etc.5620111107

Weideborg M, Vik EA, Ofjord GD, Kjonno O (1997) Comparison of three marine screening tests and four Oslo and Paris commission procedures to evaluate toxicity of offshore chemicals. Environ Toxicol Chem 16:384-389. doi:10.1002/etc.5620160238 